\title{
The Impact of Basel Standards on Financial Management: The Case of the Republic of Serbia
}

\author{
Ivana Marinović Matović \\ Faculty of Law, Security and Management ,Konstantin Veliki“, Niš, Serbia, ivana.m.matovic@gmail.com
}

\begin{abstract}
The traditional role of a financial manager, based on securing sources of financing and cash management for the smooth running of a business organization, has changed significantly over the last decades. To a large extent, external factors have contributed to that; such as the globalization of financial markets, the liberalization of capital flows, changes in the macroeconomic environment, and the development of new products and services. Basel standards have a special impact on the financial management in banking organizations. Basel standards, as the basis of regulatory regimes in banking systems around the world, have especially contributed to the development and improvement of risk management and financial management processes. This paper identifies the challenges in the process of financial management in banks in the Republic of Serbia, conditioned by Basel standards, especially regarding the capital requirements. Faced with extremely strong competition and a trend of declining margins in the banking market in the Republic of Serbia, finding the way to optimize available capital is an imperative. One of the ways is the application of advanced approaches for calculating capital requirements. Through the example of capital requirements for operational risk, the paper confirms that the advanced calculation of capital requirements is one of the ways to optimize capital and its further more productive use.
\end{abstract}

KEYWORDS: Basel standards, banking, capital requirements, financial management, Republic of Serbia

\section{Introduction}

The traditional role of a financial manager, such as providing resources of financing and handling cash management for the undisturbed business of the company, has changed significantly in recent decades. External factors have contributed to a great extent to contemporary financial management, such as the globalization of financial markets, liberalization of capital flows, changes in the macroeconomic environment, followed by the development of new products and services. All mentioned factors have additionally enhanced the importance of the financial management and its role in creating value for the company. The financial management process is gaining on importance as an integral part of strategic management, since the financial manager must contribute to the overall development goals of the company.

The scope of the strategic decisions of the contemporary financial management includes three main areas (VanHorne \& Wachovics, 2008):

- investment decisions

- decisions on financing, including decisions o dividend payment

- decisions on asset management

Investment decisions, or the structure of placements, are most important from the aspect of creating value for the company. The choice of the optimum financing structure, i.e., debt-to-capital ratio is essential for achieving the desired income for shareholders. After establishing the appropriate assets structure, it is necessary to manage it efficiently, which is the responsibility of financial management.

These three key groups of activities, responsibilities of financial management, in banks have additional specifications, motivated by the efforts of the regulator to protect depositors and indirectly provide financial stability. The constraints in the process of financial management are the satisfaction of the regulatory demands for capital adequacy. Maintenance of the minimum capital level prevents banks from taking full advantage of financial leverage. A special influence on the financial management in banks have Basel standards, that affect all three above listed areas of financial management. 


\section{Basel standards for capital adequacy and their impact on financial management}

Capital adequacy ratio in the last years of the XX'th century is becoming one of the basic indicators of success and security of banks around the world. The Basel committee defines it as a ratio of regulatory capital and risk assets, and prescribes the minimum value of $8 \%$. Starting from the first standard of capital adequacy published in 1988 (Basel I), through Basel II in 2004 to Basel III, whose implementation is expected in the following period in the Republic of Serbia, the main goal was to ensure business security of banks. Another goal of Basel standards is strengthening the resilience of the entire financial system to the shocks and risks from the environment by providing adequate capital level. Basel II is currently a widely accepted standard that regulates capital adequacy in most developed countries and it is based on three pillars:

- minimum capital requirements;

- the process of controlling capital adequacy;

- market discipline.

Providing high-quality instruments in composition of regulatory capital, banks should be able to bear the risks to which they are exposed, in particular, credit risk, market and operational, which is represented in the first pillar of the standard. The other two pillars relate to the regulator control of the process of risk management and internal assessment of capital adequacy.

Nevertheless, the global financial crisis, that escalated in 2008, showed that the application of Basel standards could not be a guarantee of the banking system stability. The breakdown of the US mortgage market in 2008 led to chain reactions worldwide. It turned out that one of the main causes of the crisis was a lack of liquidity to cover system risks arising from large credit losses. The banks that have lost most, had the inadequate capital level to absorb any potential losses, suggesting that risk management was inadequate (Basel Committee on Banking Supervision, 2013). Experiences from the crisis pointed to certain deficiencies and the need to improve the current standards of capital adequacy. In order to prevent new collapse across the world market, and strengthen the resilience of banks primarily to systemic risks, a new standard, Basel III, has been prepared. Basel III further emphasizes the importance of effective risk management, but introduces the minimum indicators for liquidity risk.

Basel standards, especially Basel II, are considered to be a turning point in operational work of contemporary banking. In addition to their key impact on strengthening the risk management process, the financial management process has also been influenced and experienced changes. The financial management process has been improved by setting a series of restrictions. These restrictions relate to level and structure of capital and other borrowed sources of financing. Restrictions also include the structure and level of banks' placements, with the goal of achieving the capital adequacy indicators at the prescribed level. Financial management determines the optimal level of the regulatory capital versus the risks. The optimal level of the regulatory capital should protect the bank from the expected and unexpected losses. It should meet the prescribed minimum requirements on the one hand, and on the other hand provide satisfactory shareholder's return on invested funds. The connection between capital and risk is represented by capital requirements for credit, market and operational risk. Capital requirements are determined as a fixed percentage of risk assets for each of the individual risks. Capital requirements are directly depend on the selected calculating model.

Basel III further sets limits and constraints, quite challenging for financial management, which arise from the novelty it brings regarding the structure of capital and other sources of financing. The most important are the following:

- Core capital (Tier 1) consists of share capital and unallocated profit, which can be included in equity before the decision of the shareholders' meeting, where the minimum of share capital is set at the level of $4.5 \%$ of risk assets, while the total core capital is $6 \%$ of the risk assets;

- Two new capital reserves were introduced: Capital Conservation Buffer and Countercyclical Capital Buffer. Capital Conservation Buffer should be $2.5 \%$ of the risk-weighted assets and the full implementation of this standard will begin on 1. January 2019. Countercyclical Capital Buffer was introduced with the aim of limiting risk in the financial system during periods of high credit growth, and is determined in the amount of $0 \%$ to $2.5 \%$ of the risk-weighted assets. 
- A leverage ratio is introduced as a relationship between capital and total exposure. It is expected that from 2013 the leverage ratio is tested at the level of 3\%, which was taken for the limit value. The obligation to publish this indicator starts from 2015, while it is being introduced as part of the first pillar of the Basel standard from 2018.

- As overcoming of Basel II deficiencies, two minimum standards of liquidity are introduced: Liquidity Coverage Ratio, as an indicator of short-term liquidity, and Net Stable Funding Ratio, as an indicator of long-term liquidity. The bank should have a highly liquid assets that can be easily converted into cash, in the event of an unexpected event in liquidity segment.

These novelties directly influence the financial management process in banks. Introducing the limits for share and core capital in relation to risk assets, strives to strengthen the position of the bank from the aspect of high quality capital. Capital requirements, on the other hand, represent an additional motive for optimal use of this most expensive source of financing. Limiting the profit distribution affects the bank's dividend policy, as one of the key decisions of the financial management. By prescribing the level of leverage ratio, not conceived at the risk assets, the structure of the funding sources is additionally limited. Finally, introducing the short-term and long-term liquidity ratios affects daily cash management, other highly liquid assets and short-term sources of financing. Basel III standards, in addition to strengthening and improving the risk management, directly influence the daily decisions of financial management.

\section{Basel standards in the Republic of Serbia}

Basel II is applied in the Republic of Serbia from 1st January 2012, based on several decisions of the National Bank of Serbia. These are: Decision on capital adequacy, Decision on risk management, Decision on publishing data and information of the bank, Decision on reporting on capital adequacy, Decision on the reporting of banks and Decision on control of the banking group on a consolidated basis. Decision on capital adequacy refers to the implementation of the first pillar of Basel II, determination of capital adequacy. Accordingly, banks are required to calculate individual capital adequacy for credit, market and operational risk, and an indicator of capital adequacy should be at least $12 \%$.

Based on the National Bank of Serbia (NBS 2015), an indicator of capital adequacy was $19.96 \%$, which is significantly above the regulatory limit. In the structure of capital requirements, the capital requirements for credit risk are prevailing with $86 \%$, followed by capital requirements for operational risk with $12 \%$, and ultimately for market risk with $2 \%$, which is in line with the dominant activities of banks in Serbia.

In the banking sector of the Republic of Serbia, all banks use a standard approach for the calculation of capital requirements for credit and market risk, while for operational risk only $13.8 \%$ of banks apply a standard approach (NBS 2015). Other banks apply a basic indicator approach, while an advanced approach is not applicable by any bank. In the surrounding countries, but also in the developed countries (that are owners of the largest number of banks operating at the Serbian market), the situation is similar in terms of market and operational risks, while for calculating the credit risk internal models are also used. Table 1 represents an overview of the models for calculation of capital requirements in selected countries.

Table 1: Models for calculation of capital adequacy

\begin{tabular}{|cccccccccc|}
\hline Credit risk & Austria & Germany & Italy & France & Greece & Hungary & Romania & Bulgaria & Croatia \\
\hline Standard & $91,4 \%$ & $99,9 \%$ & $91,0 \%$ & $38,1 \%$ & $100,0 \%$ & $95,6 \%$ & $100,0 \%$ & $95,8 \%$ & $100,0 \%$ \\
\hline FIRB & $8,4 \%$ & $0,9 \%$ & $3,2 \%$ & $0,0 \%$ & $10,0 \%$ & $0,6 \%$ & $6,5 \%$ & $4,2 \%$ & $2,9 \%$ \\
\hline AIRB & $0,2 \%$ & $1,8 \%$ & $5,9 \%$ & $61,9 \%$ & $0,0 \%$ & $3,8 \%$ & $3,2 \%$ & $0,0 \%$ & $2,9 \%$ \\
\hline Market risk & & & & & & & & & \\
\hline Standard & $98,3 \%$ & $34,7 \%$ & $99,2 \%$ & $52,2 \%$ & $100,0 \%$ & $100,0 \%$ & $100,0 \%$ & $100,0 \%$ & $100,0 \%$ \\
\hline VAR & $1,7 \%$ & $0,6 \%$ & $0,8 \%$ & $47,8 \%$ & $15,0 \%$ & $0,0 \%$ & $0,0 \%$ & $0,0 \%$ & $0,0 \%$ \\
\hline $\begin{array}{c}\text { Operational } \\
\text { risk }\end{array}$ & & & & & & & \\
\hline
\end{tabular}




\begin{tabular}{|cccccccccc|}
\hline BIA & $95,2 \%$ & $96,8 \%$ & $88,2 \%$ & $32,4 \%$ & $75,0 \%$ & $88,8 \%$ & $80,6 \%$ & $83,3 \%$ & $68,6 \%$ \\
\hline SA & $3,4 \%$ & $2,3 \%$ & $5,4 \%$ & $41,4 \%$ & $30,0 \%$ & $5,6 \%$ & $9,7 \%$ & $12,5 \%$ & $25,7 \%$ \\
\hline AMA & $1,4 \%$ & $0,9 \%$ & $6,4 \%$ & $26,2 \%$ & $0,0 \%$ & $5,6 \%$ & $9,7 \%$ & $4,2 \%$ & $5,7 \%$ \\
\hline
\end{tabular}

Source: European Banking Authority (2013)

The application of internal models for calculating capital requirements has the widest use in France. Analyzing the surrounding countries, the basic indicator approach for operational risk is less used only in Croatia, compared to the Republic of Serbia. This situation reflects on one hand unwillingness of institutions to switch to more complex advanced calculation models, but on the other hand, reflects the prudent regulation due to the use of a more conservative standard approach.

Although one of the basic goals of financial management is capital optimization, this requirement can not be achieved without close cooperation with the risk management, without considering the risk profile of the bank. Faced with limited possibilities and defined risk levels, one of the ways to optimize the capital is the application of advanced approaches for calculating capital requirements. The optimisation of capital could be achieved by standard approach for calculation of capital requirements for operational risk. In accordance with Basel II, the application of the standard approach requires the distribution of banks' operations into eight business lines. The indicator for operational risk should be calculated for each business line. Thereafter the capital requirement for operational risk is obtained as a product of an exposure indicator and a particular beta coefficient that takes values from 12\% to $18 \%$ (NBS, Decision on Capital Adequacy 2015). Total capital requirement for operational risk is equal to the sum of capital requirements for each individual business line. Versus this calculation, the application of the simplest basic indicator approach means that the exposure indicator is multiplied by the alpha coefficient equal to $15 \%$, and the product represents the total capital requirement for operational risk. In both cases an exposure indicator represents the sum of net interest income and net non-interest income, in accordance with the Decision on capital adequacy. An example of the two largest banks in the Republic of Serbia, that apply a standardized approach, shows that they allocate less capital compared to the basic indicator approach. Thus increases a certain amount of capital for further productive use, and the higher indicator of capital adequacy. From the operational point of view, the application of standard approach is dependent on the separation of revenues and expenditures between the business lines from which they originate.

The standardized approach, compared to the basic indicator, means a lower capital requirement, in particular with banks that have a relatively significant share of business with the private individuals and the small and medium enterprises. Lower capital requirements are the result of calculation using a beta coefficient at $12 \%$, instead of $15 \%$ with alpha coefficient.

Tables 2 and 3 show the calculation of capital adequacy for operational risk in the two largest banks in Serbia for 2016 (Narodna banka Srbije, 2017), using the standardized approach.

Table 2. Calculation of capital adequacy for operational risk in Banca Intesa, 2016

\begin{tabular}{|c|c|c|c|c|c|}
\hline Banca Intesa (000 rsd) & \multicolumn{3}{|c|}{ Exposure indicator } & \multirow{2}{*}{$\begin{array}{c}\text { b - Rate } \\
\text { of capital } \\
\text { adequacy }\end{array}$} & \multirow[t]{2}{*}{ Capital adequacy } \\
\hline Business line & 2014 & 2015 & 2016 & & \\
\hline Corporate financing & 0 & 0 & 0 & $18 \%$ & \multirow{8}{*}{4.294 .527} \\
\hline Treasury & 5.719 .753 & 8.276 .167 & 7.144 .237 & $18 \%$ & \\
\hline Trading operations PI & 3.298 & 4.217 & 1.960 & $12 \%$ & \\
\hline $\begin{array}{c}\text { Banking operations } \\
\text { corporate }\end{array}$ & 11.679 .226 & 10.251 .285 & 8.242 .863 & $15 \%$ & \\
\hline Banking operations PI & 11.312 .395 & 12.797 .558 & 13.677 .527 & $12 \%$ & \\
\hline Settlement & 31.140 & 31.753 & 26.302 & $18 \%$ & \\
\hline Services & 1.484 & 1.765 & 1.132 & $15 \%$ & \\
\hline Asset management & 0 & 0 & 0 & $12 \%$ & \\
\hline
\end{tabular}


Table 3. Calculation of capital adequacy for operational risk in Komercijalna Bank, 2016

\begin{tabular}{|ccccc|}
\hline Komercijalna Bank (000 rsd) & \multicolumn{3}{c}{ Exposure indicator } & $\begin{array}{c}\boldsymbol{\beta} \text { - Rate } \\
\text { of capital } \\
\text { adequacy }\end{array}$ \\
\cline { 1 - 5 } Business line & $\mathbf{2 0 1 4}$ & $\mathbf{2 0 1 5}$ & $\mathbf{2 0 1 6}$ & Capital adequacy \\
\hline Corporate financing & 8.476 & 6.611 & 5.498 & $18 \%$ \\
\hline Treasury & 582.162 & -1.980 .285 & -295.514 & $18 \%$ \\
\hline Trading operations PI & 5.032 & 5.722 & 6.200 & $12 \%$ \\
\hline Banking operations corporate & 10.136 .666 & 14.187 .748 & 7.343 .568 & $15 \%$ \\
\hline Banking operations PI & 6.763 .964 & 5.278 .501 & 10.876 .460 & $12 \%$ \\
\hline Settlement & 1.932 .184 & 1.990 .472 & 2.034 .688 & $18 \%$ \\
\hline Services & 28.995 & 26.320 & 47.597 & $15 \%$ \\
\hline Asset management & 77.087 & 203.192 & 163.051 & $12 \%$ \\
\hline
\end{tabular}

Source: Komercijalna Banka ad Beograd (2017)

By applying a standardized approach for calculating the capital requirements for credit, market and operational risk, indicators of capital adequacy are $22,00 \%$ in Banca Intesa, and 26,15\% in Komercijalna Banka. In the case of basic indicator approach, used in mentioned banks for the same period of the calculation, the capital requirements would be higher, as well as the indicator of capital adequacy. This calculation is shown in Table 4.

Table 4. Comparative analysis of capital requirements, standard vs. basic indicator approach

\begin{tabular}{|lcc|}
\hline$(000$ rsd $)$ & Banca Intesa & $\begin{array}{c}\text { Komercijalna } \\
\text { banka }\end{array}$ \\
\hline Capital requirement for operational risk - Standard approach & 4.294 .527 & 2.780 .771 \\
\hline Capital requirement for operational risk - Basic indicator approach & 4.364 .103 & 3.027 .232 \\
\hline Reduction of capital requirement for operational risk & 69.576 & 246.461 \\
\hline Reduction of capital requirement for operational risk (\%) & $1,59 \%$ & $8,14 \%$ \\
\hline Total capital requirements - Standard approach for operational risk & 33.110 .489 & 23.815 .629 \\
\hline Capital adequacy indicator - Standard approach for operational risk & $22,00 \%$ & $26,15 \%$ \\
\hline Total capital requirements - Basic indicator approach for operational risk & 33.180 .065 & 24.062 .090 \\
\hline Capital adequacy indicator - Basic indicator approach for operational risk & $22,05 \%$ & $26,42 \%$ \\
\hline
\end{tabular}

\section{Source: Author}

Based on the research calculations, it can be verified that use of a standard approach for calculating the capital requirement for operational risk leads to the lower capital requirements. These parts of the capital could be used productively. Research has shown that the capital requirement for operational risk was reduced by $1,59 \%$ in Banca Intesa, while in Komercijalna Banka it was decreased by $8,14 \%$ (Table 4).

\section{Results and discussions}

The presented research analysis indicates that banks in the Republic of Serbia should use a standard approach of calculations for capital requirements for operational risks. Use of standard approach would have positive effects on the total capital requirements and an indicator of capital adequacy. Also, it would optimize partially the capital for given risks. Considering the dominant use of the basic indicator with banks in the Republic of Serbia, banks should improve the process of risk management as well as financial management, by moving to more advanced standard approach.

Novelty foreseen by Basel III will set important requirements before the banking sector of the Republic of Serbia. However, according to the results of the quantitative study regarding the impact of Basel III on capital, risky assets and leverage ratios in 2015 (Narodna Banka Srbije, 2015), the banking 
sector of the Republic of Serbia is adequate and highly capitalized. This means that banks of the Republic of Serbia could easily satisfy the new minimum capital requirements. The Basel III application will lead to the increase of capital adequacy ratio, due to growth of total regulatory capital. All banks would satisfy minimum prescribed indicators of the capital adequacy, of the core and total capital, while most banks would have an indicator of the share capital adequacy above the prescribed level.

The impact of the liquidity indicators introduction will be analyzed in the future period by the regulatory bodies. However, the introduction of liquidity coverage indicators implies that banks will be more focused on long-term sources of financing and low-yield liquid forms of assets, which has a direct impact on profitability. Satisfying the given indicators will result in decrease of net interest margins of banks, because the share of inexpensive sources will be reduced in the structure of financing. It is possible to expect that more successful banks will have a higher amounts of net stable sources of financing, and will significantly influence the assets price, while less successful banks will face the problem of competitiveness (Mirković 2012).

\section{Conclusion}

Basel standards, as the regulative basis in banking systems around the world have contributed to the development and improvement the risk management process, and the improvement of the financial management. Financial managers are required to respect the limitations in terms of management of the financing sources and making decisions on the profit allocation. Financial managers need to reach the appropriate ratio between capital and risk, and therefore ensure the satisfaction of the prescribed minimum indicator of capital adequacy. Too high indicator of capital adequacy indicates that capital is unproductive, while a low level of indicators warns that the bank does not have enough capital to cover possible losses, arised from the assumed risks. Faced with extremely strong competition and trend of margins declining in the Republic of Serbia, finding the way of optimization of available capital is imperative. One way of optimization is the application of advanced approaches for calculating capital requirements. In the future period, adjusment of legal regulatives and business operations of banks to Basel III standards is expected. This will additionally influence the day-to-day financial management in banking institutions in order to fulfill the liquidity ratios.

\section{References}

Banca Intesa a.d. Beograd. 2017. Bazel II Stub 3: Objavljivanje podataka i informacija banke sa stanjem na dan 31.12.2016. godine, http://www.bancaintesa.rs/upload/Banca_Intesa__Basel_2_Pilar_3_31.12.2016..pdf. Accessed June 15, 2018.

Bank for International Settlements. 2004. International convergence of capital measurement and capital standards. http://www.bis.org/publ/bcbs107.pdf. Accessed June 1, 2018.

Bank for International Settlements. (2009). Strengthening the resilience of the banking sector. www.bis.org/publ/bcbs164.htm. Accessed June 2, 2018.

European Banking Authority. 2013. Aggregate statistical data. http://www.eba.europa.eu/supervisoryconvergence/supervisory-disclosure/aggregate-statistical-data. Accessed June 1, 2018.

Komercijalna banka a.d. Beograd. 2017. Izveštaj o objavljivanju podataka i informacija Grupe Komercijalna banka a.d. Beograd za 2016. Godinu. https://www.kombank.com/pdf/izvestaj_opi_grupe_31_12_2016.pdf. Accessed June $16,2018$.

Mirković, V. 2012. Bankarski sektor Srbije - ostvarene performanse i izazovi u budućnosti. Ekonomski vidici, 17(4), 643662.

Narodna banka Srbije (NBS). 2015. Rezultati kvantitativne studije uticaja novih standarda o kapitalu, rizičnoj aktivi $i$ leveridžraciju.http://www.nbs.rs/export/sites/default/internet/latinica/55/55_2/bazel_3/rezultati_studije_uticaja_n ovih_standarda.pdf. Accessed June 1, 2018.

Narodna banka Srbije (NBS). 2017. Bankarski sektor u Srbiji Izveštaj za IV tromesečje $2016 . \quad$ godine. https://www.nbs.rs/internet/latinica/55/55_4/kvartalni_izvestaj_IV_16.pdf. Accessed June 2, 2018.

Službeni glasnik RS. 2011. Odluka o adekvatnosti kapitala banke. Službeni glasnik RS, br. 46/2011, ispravka 46/2011. Van Horne J., and Wachowicz, J. 2008. Fundamentals of Financial Management. Upper Saddle River, NJ: Prentice Hall. 